\title{
IKAP
}

JKAP (Jurnal Kebijakan dan Administrasi Publik)

Vol.21 (2), November 2017, 155-167

ISSN 0852-9213 (Print), ISSN 2477-4693 (Online)

Available Online at https://journal.ugm.ac.id/jkap

\section{Collaborative Governance Model in Managing International Borders in Riau Islands Province Using Partial Least Squares Method}

\author{
Adji Suradji Muhammad \\ Universitas Maritim Raja Ali Haji \\ suradji@umrah.ac.id \\ Tulus Warsito \\ Universitas Muhammadiyah Yogyakarta \\ tulusw_umy@yahoo.com \\ Ulung Pribadi \\ Universitas Muhammadiyah Yogyakarta \\ ulungpribadi@ymail.com \\ Achmad Nurmandi \\ Universitas Muhammadiyah Yogyakarta \\ nurmandiachmad@gmail.com
}

\begin{abstract}
Despite the large number of border management agencies at both local and national level, there is no guarantee that borders of Riau Islands Province are well protected. Most illegal fishing, mining and human trafficking are attributable to the lack of collaboration among various border management agencies. It also indicates failure to implement effectively collaborative culture, leadership, team process, structure, and strategic vision. This study aims to evaluate the implementation of Collaborative Governance Model in the management of Riau Islands Province borders. The study used a descriptive verification method, and collected data using an interview technique, while partial least squares method was used in analyzing the data. Results swhowed that the collaborative team process (CTP), turned out to be the dependent variable, while the other five principles, , inter alia, structural, cultural, leadership and strategic vision variables were established as the indepdendentindependent variables that influence CTP.
\end{abstract}

Keywords: collaborative governance; border between countries; welfare 


\section{INTRODUCTION}

Indonesia is located in a strategically importance geopolitical position as it shares borders with 10 countries, inter alia Singapore, Malaysia, the Philippines, India, Vietnam, Thailand, Cambodia, Palau Republic, Papua New Guinea (PNG) and Australia. Nonetheless, most Indonesian international borders are maritime in nature, and shares terrirotial international borders with only three countries: Malaysia, Papua, Papua New Guinea (PNG), and Timor and Timor Leste. Riau Islands province, is one of the provinces in Indonesia that shares international borders with four countries that is Malaysia, Singapore, Vietnam, and Cambodia. Based on Presidential instruction No. $78 / 2005$ on the management of small remote islands that form international borders with other countries, which that stipulates that Riau islands province has 19has 19 small islands that form international borders with other countries. The 19 islands are located in 5 in 5 district/city administrations and share international borders with four countries: Malaysia, Singapore, Vietnam and Cambodia.

Protecting national security is one of the mandates that are enshrined in the 1945 constitution 1945 constitution. To that end, protecting international borders as part of that mandate, is very strategically important as well to such an extent that the government issued government regulation No. 26/ 2008 on National Spatial regional plan. Indonesia has agencies that are charged with managing international borders at the national, province, district/city government level. At the national level, the, the government established the National International Borders Management Agency (BNPP), which is based on presidential regulation No. $12 / 2010$ on 2010 on BNPP. BNPP has 15 members, 10 of whom are representatives of Ministries, 4, 4 representatives of national agencies, and Governor, and 3 advisors who are drawn from the Coordinating ministry.

Meanwhile at the sub national level (Province, and district/city governments), the legal framework is based on the Ministry of internal affairs regulation No. 02/ 2011 on guidelines for the formation of re- gional agency for the management of international borders. Riau islands province, as, as one of the provinces that shares international borders with four countries, has (1) one regional international borders management agency (BPPD) at the province level, and 5 and 5 (five) regional international borders management agencies at the district/city government level. Besides, Indonesia, Indonesia also has several other agencies that are charged with functions with functions and tasks that relate to the management of international borders. The agencies, among others include National Maritime security agency (BAKAMLA), Marine forces of the Republic of Indonesia (TNI AL), and Air and Sea Police (POLAIRUD).

Nonetheless, the existence of many institutions and agencies that are responsible for the management of international borders does not by itself guarantee security of areas that share international borders with other countries. This also applies to security of international borders in Riau island province. The province faces problems that relate to proximity to international borders such as smuggling, pirates, illegal, illegal fishing, illegal mining and others. The frequency of the above problems, is among other factors attributable to poor cooperation among the various agencies that manage international borders. Nonetheless, cooperation or collaboration is meaningless without participation (Newman, Barnes, Sullivan, \& Knops, 2004).

In light of the foregoing, there, there is need for serious, concerted, concerted and integrated efforts to find long term solution to problems that plague international border areas. Collaboration among agencies that conduct functions that relate to managing international borders should mitigate even find solutions to problems faced. In a research by (Richie, Oppenheimer, \& Clark, 2012) showed that after years of forming collaboration, fosters the creation of a policy framework that explicitly involves stakeholders through dialog, enhances decision making skills, and drawing consensus based recommendations.

According to (Lai, 2011), "Collaboration is the mutual engagement of 
participants in a coordinated effort to solve a problem together. Collaborative interactions are characterized by shared goals, symmetry of structure, and a high degree of negotiation, interactivy, and interdependence. Collaboration is driving force for all individuals who occupy public positions in politics, not only because the process offers everything to everybody, rather due to the fact that collaboration has a relationship with program process, agenda, and outcome. Collaboration also encourages the process of making a choice to achieve something.

Collaborative governance, which involves many parties, both in government and private sector, is, is one the ways to find collective solutions to common problems. Nonetheless, to achieve its goals, collaborative Governance must be based on a grand design or master plan (Emerson, Nabatchi, $\&$ Balogh, 2012). The formulation the master plan or blueprint, which is currently underway, while serves as a guide in the management of international borders, has not involved such relevant stakeholders as regional international border management agency at the province and district/city government level. In other words, the blueprint does not involve representatives of the subnational governments. Besides the blue print has not also involved the general public and non-governmental organizations.

Using a collaborative approach among institutions that are charged with managing international borders as stipulated in Presidential regulation No. 12/2010 on BNPP and complemented by Law No 23/ 2014 on local government, should help to find solutions to the problems. Thus, the existence of a legal framework that fosters and facilitates the involvement of stakeholders at all tiers of government at national and subnational level alike, can help in finding solutions to problems that affect international borders at the national and local government level. In light of that, the objective of this research is to analyze the performance of the collaborative governance model in thein the management of international borders in Riau island province.

\section{Conceptual Framework}

Collaboration is a complex process, which demands planned, intentional knowledge sharing that becomes the responsibility of all parties (Lindeke and Sieckert, 2005). Moreover, Edward M Marshal (1995) contends that collaboration is a process is lays the foundation for the emergency of trust based cooperation, integrity, and breakthroughs achieved through consensus, ownership, and bringing together all aspects of the organization.

In as much as the function or task that requires or involves other parties, collaboration is always needed hence not confined to certain time or period. This is elucidated by (Anderson \& McFarlane, 2000) who notes defines collaboration as sustained interaction process between several individuals. In executing collaboration, joint planning is necessary in order to ensure all parties to the collaboration bear joint accountability for the task or responsibility that is implemented jointly. This is underscored in a research by (Lindeke \& Sieckert, 2005) who contends that collaboration being a complex process, requires knowledge sharing that is planned beforehand, deliberate, and demands joint accountability.

According to (Gray \& Wood, 1991), collaboration faces 7 (seven) obstacles, including ; 1). Commitment that is in contravention with collaboration, 2). Long history of enmity that is based on ideology, $3)$.Condition were policy does not take into account the allocation of resources, 4). Differences in perception about risk, 5). Technical difficulties, 6). Institutional and political culture /illegitimacy, and 7). Unilateral action by one or more parties to the collaboration.

To that end, to maximize collaboration outcomes, collaborators must pay attention several to a number of issues that include culture, leadership, strategy used, the team involved, and institutional structure. This is line with what Djumara (2008) contends when he proposes that an five components must be fulfill five components:

1. Collaborative Culture, is an embodiment of basic values that influence business behavior and attitude. This specifically refers to the culture of individuals who forge collaboration. 
2. Collaborative Leadership, entails sense of collectivism or cooperation that is based on function or task to be carried out rather than motivated by hierarchal positions of all individuals in the organization.

3. Strategic Vision, relates to guidance principles or goals of the organization that are based on learning and knowledge about strategic internal collaboration, which is specifically tailored toward enhancing valued added in the market.

4. Collaborative Team Process. In a collection of non-bureaucracy work process that falls under the management of a professional collaborative team that shoulders full responsibility for the success of the task or function and learns requisite skills required for an independent execution.

5. Collaborative Structure. Making improvement on the business support systems (especially information system and human resources) in order to ensure collaborative work achieves planned outcome. Members of the collaboration, who are drawn from the organization perceive the organization the way customers do, which enables them to focus all their work on enhancing quality.

\section{Collaborative Governance}

Ansell and Gash attempt to define Collaborative Governance as follows: " $A$ governing arrangement where one or more public agencies directly engage non-state stakeholders in a collective decision-making process that is formal, consensus-oriented, and deliberative and that aims to make or implement public policy or manage public programs or assets" (Ermaya Suradinata, 1998). Every members of the collaborative team is responsible for executing those tasks that are assigned to it, while at the same time harnessing coordination with other members of the team in planning and implementing programs of public interest.

The criteria used in a Collaborative Governance, entails (1) the forum is initiated by public agencies; (2) participants in the forum include non-state actors; (3) participants engage in decision making and are not merely "consulted"; (4) the forum is formally organized; (5) the forum aims to make decisions by consensus; and (6) the focus of collaboration is on public policy or public management (Emerson et al., 2011). In addition, Ansel and Gash continue, implementing Collaborative Governance is important because it is based on developments in the organization and advancement in institutional knowledge and capacity or in line with experiences the organization gets from the environment as long as the organization is functional or a going concern within a certain period (Sudarmo, 2011).

\section{Borders and Border areas}

The general definition of international borders, based on Rizal (2009), refers to a demarcation line that separates two independent countries or nations (Rizal Darmaputra, 2009). Meanwhile, The Indonesian language dictionary defines an international border as "an area" (authority, government, supervision, and so on ), while "region" is defined as a certain area which has certain characteristics, such as place of residence, stores or shops, industry, and so on. With regards to the definition used in Law No.43/2008, an international border is starkly different from other areas in the country. In article 1, No. 6 , stipulates that an international border area is part of the republic of Indonesia that is located along the region that separates the territorial and sea area that falls under the jurisdiction of the republic of Indonesia and those that belong to other countries.

\section{RESEARCH METHODS}

This is a descriptive and qualitative research. Research methods will shed light on the relationships among variables that is significant, which in turn will help in drawing conclusions on the research object (Narimawati, 2010). In other words, the research analysis is based on qualitative information and data.

The research analyses factors that are important in forming Collaborative Governance in the management of international border areas in Riau island province. Variables 
Adji Suradji Muhammad, Tulus Warsito, Ulung Pribadi, Achmad Nurmandi - Collaborative Governance...

Table 1. Institutions and Actors involved in the Management of International Borders in Riau islands Province

\begin{tabular}{|c|c|c|}
\hline No. & Institution & Official \\
\hline 1 & Ministry of Internal affairs & $\begin{array}{l}\text { Director for regional, Urban and Interna- } \\
\text { tional borders }\end{array}$ \\
\hline 2 & Ministry of Foreign affairs & Director General for multilateral afairs \\
\hline 3 & Ministry of Defense & Directorate General for Defense forces \\
\hline 4 & Ministry of Legal and human rights affairs & Directorate of Immigration \\
\hline 5 & Ministry of Finance & Directorate of Excise and Customs \\
\hline 6 & Ministry of Public works & Directorate of Rivers and Coasts \\
\hline 7 & Ministry of Transportation & $\begin{array}{l}\text { Directorate of Unified Protection of Mari- } \\
\text { time and Coastal areas }\end{array}$ \\
\hline 8 & Ministry of Forestry & $\begin{array}{l}\text { Directorate General for Environmental } \\
\text { Pollution and Degradation. }\end{array}$ \\
\hline 9 & Ministry of Marine and Fisheries & Directorate of empowering small islands \\
\hline 10 & $\begin{array}{l}\text { Ministry of National Development Plan- } \\
\text { ning /Head of National development plan- } \\
\text { ning Board }\end{array}$ & $\begin{array}{l}\text { Director for Defense and Security, Director } \\
\text { for regional development }\end{array}$ \\
\hline 11 & Ministry of Underdeveloped areas & $\begin{array}{l}\text { Directorate general of development for spe- } \\
\text { cific areas }\end{array}$ \\
\hline 12 & Commander of the Indonesian Armed Forces & $\begin{array}{l}\text { Aster Commander of Indonesian armed } \\
\text { forces }\end{array}$ \\
\hline 13 & Indonesian National Police force & National security preservation agency \\
\hline 14 & National Intelligence agency & Deputy in charge of Economic intelligence; \\
\hline 15 & $\begin{array}{l}\text { National Survey coordination and mapping } \\
\text { Agency/BIG National Geospatial infor- } \\
\text { mation agency }\end{array}$ & $\begin{array}{l}\text { Deputy in charge of Basic Geospatial infor- } \\
\text { mation }\end{array}$ \\
\hline 16 & Governor, Riau islands rovince & $\begin{array}{l}\text { Regional development planning agency } \\
\text { (BAPPEDA) }\end{array}$ \\
\hline 17 & $\begin{array}{l}\text { National Maritime security agency BA- } \\
\text { KAMLA Presidential regulation } 178 / 2014\end{array}$ & $\begin{array}{l}\text { National Maritime security agency } \\
\text { (Bakamla) }\end{array}$ \\
\hline 18 & BP Riau Islands province & BP Riau Islands province \\
\hline 19 & $\begin{array}{l}\text { Batam city international borders and Secu- } \\
\text { rity agency }\end{array}$ & $\begin{array}{l}\text { Batam city international borders and Se- } \\
\text { curity agency }\end{array}$ \\
\hline 20 & $\begin{array}{l}\text { Bintan international borders protection agen- } \\
\text { cy (BPP Bintan) }\end{array}$ & $\begin{array}{l}\text { Bintan international borders protection } \\
\text { agency (BPP Bintan) }\end{array}$ \\
\hline 21 & $\begin{array}{l}\text { Natuna international borders protection } \\
\text { agency (BPP Natuna) }\end{array}$ & $\begin{array}{l}\text { Natuna international borders protection } \\
\text { agency (BPP Natuna) }\end{array}$ \\
\hline 22 & $\begin{array}{l}\text { Karimun international borders protection } \\
\text { agency (BPP Karimun) }\end{array}$ & $\begin{array}{l}\text { Karimun international borders protection } \\
\text { agency (BPP Karimun) }\end{array}$ \\
\hline 23 & $\begin{array}{l}\text { Anambas islands international borders pro- } \\
\text { tection agency (BPP Kepulauan Anambas) }\end{array}$ & $\begin{array}{l}\text { Anambas islands international borders pro- } \\
\text { tection agency (BPP Kepulauan Anambas) }\end{array}$ \\
\hline
\end{tabular}

that are used in then research are based on those proposed by (Djumara, 2008) which consist of 5 dimensions and derived variables that include:

1. Collaborative Culture.

2. Collaborative Leadership.

3. Strategic Vision
4. Collaborative Team Process

5. Collaborative Structure

The five variables will subsequently be subjected to testing to determine the level of significance in explaining a certain concept in relation to solving an international border problem. 
Table 2. Discriminant Validity Results

\begin{tabular}{lcccccc}
\hline Variable & $\begin{array}{c}\text { Collabora- } \\
\text { tive Culture }\end{array}$ & $\begin{array}{c}\text { Collaborative } \\
\text { Governance }\end{array}$ & $\begin{array}{c}\text { Collaborative } \\
\text { Leadership }\end{array}$ & $\begin{array}{c}\text { Collabora- } \\
\text { tive Struc- } \\
\text { ture }\end{array}$ & $\begin{array}{c}\text { Collabora- } \\
\text { tive Team }\end{array}$ & $\begin{array}{c}\text { Strategic } \\
\text { Vision }\end{array}$ \\
\hline $\mathrm{X} 1.1$ & 0.894 & 0.874 & 0.735 & 0.800 & 0.809 & 0.837 \\
\hline $\mathrm{X} 1.2$ & 0.856 & 0.638 & 0.572 & 0.480 & 0.479 & 0.461 \\
\hline $\mathrm{X} 1.3$ & 0.724 & 0.469 & 0.546 & 0.269 & 0.304 & 0.269 \\
\hline $\mathrm{X} 2.1$ & 0.631 & 0.720 & 0.866 & 0.605 & 0.541 & 0.639 \\
\hline $\mathrm{X} 2.2$ & 0.599 & 0.595 & 0.810 & 0.471 & 0.445 & 0.515 \\
\hline $\mathrm{X} 2.3$ & 0.713 & 0.714 & 0.833 & 0.569 & 0.537 & 0.555 \\
\hline $\mathrm{X} 3.2$ & 0.710 & 0.850 & 0.507 & 0.803 & 0.920 & 0.856 \\
\hline $\mathrm{X} 3.3$ & 0.659 & 0.863 & 0.653 & 0.919 & 0.824 & 0.897 \\
\hline $\mathrm{X} 4.1$ & 0.468 & 0.787 & 0.630 & 0.786 & 0.781 & 0.861 \\
\hline $\mathrm{X} 4.2$ & 0.662 & 0.713 & 0.408 & 0.621 & 0.791 & 0.726 \\
\hline $\mathrm{X} 4.3$ & 0.677 & 0.940 & 0.701 & 0.979 & 0.932 & 0.960 \\
\hline $\mathrm{X} 5$ & 0.473 & 0.737 & 0.413 & 0.769 & 0.834 & 0.769 \\
\hline $\mathrm{Y} .1$ & 0.695 & 0.944 & 0.660 & 1.000 & 0.939 & 0.961 \\
\hline $\mathrm{Y} .2$ & 0.982 & 0.787 & 0.734 & 0.610 & 0.625 & 0.612 \\
\hline $\mathrm{Y} .3$ & 0.777 & 0.820 & 0.988 & 0.667 & 0.616 & 0.684 \\
\hline $\mathrm{Y} .4$ & 0.694 & 0.950 & 0.671 & 0.941 & 0.970 & 0.994 \\
\hline Y.5 & 0.719 & 0.949 & 0.628 & 0.948 & 0.998 & 0.973 \\
\hline & 0.695 & 0.944 & 0.660 & 1.000 & 0.939 & 0.961 \\
\hline
\end{tabular}

The research used primary data, which was obtained using a questionnaire that was sent to stakeholders that are relevant to the issue of managing international borders in Riau Island province.

The questionnaire had a hard copy and soft copy version. The hard copy was a print out of the questionnaire before it was sent to respondents, while the soft copy was a file that contains the questions, developed based on Google form. Respondents in this research consisted of officials who hold authority and positions that relate to the management of international borders at the national, provincial, district/city government level (Table 1).

Data obtained using questionnaires was subsequently analyzed using Partial Least Squares (PLS) statistics tool. PLS is a parametric technique that is used to test the significance of parameters. The analysis was based on an outer model that was determining discriminant validity and convergent validity of indicators in the model (Hair, Sarstedt, Hopkins, \& Kuppelwieser, 2014).

\section{RESULTS AND DISCUSSION}

\section{Discriminant Validity}

Results of tests on discriminant validity and convergent validity based on cross loadings, were based on the notion that an item is determined to be valid if the value of its correlation with its variable is higher that the value of its correlation with other variables (Table 2). For instance, item X1.1, the value of its highest correlation is 0.894 with Collaborative Leadership but the value of its correlation of X1.1 with other variables is smaller than 0.894 .

Meanwhile, results of Convergent Validity is determined on the basis of the corre- 
Adji Suradji Muhammad, Tulus Warsito, Ulung Pribadi, Achmad Nurmandi - Collaborative Governance...

Table 3. Outer Loading Results

\begin{tabular}{|c|c|c|c|c|c|c|}
\hline Item & $\begin{array}{l}\text { Collabora- } \\
\text { tive Culture }\end{array}$ & $\begin{array}{l}\text { Collaborative } \\
\text { Governance }\end{array}$ & $\begin{array}{c}\text { Collaborative } \\
\text { Leadership }\end{array}$ & $\begin{array}{l}\text { Collaborative } \\
\text { Structure }\end{array}$ & $\begin{array}{l}\text { Tim Collabo- } \\
\text { rative }\end{array}$ & $\begin{array}{l}\text { Strategic } \\
\text { Vision }\end{array}$ \\
\hline $\mathrm{X} 1.1$ & 0.849 & & & & & \\
\hline $\mathrm{X} 1.2$ & 0.856 & & & & & \\
\hline $\mathrm{X} 1.3$ & 0.724 & & & & & \\
\hline $\mathrm{X} 2.1$ & & & 0.866 & & & \\
\hline $\mathrm{X} 2.2$ & & & 0.810 & & & \\
\hline $\mathrm{X} 2.3$ & & & 0.833 & & & \\
\hline X3.1 & & & & & & 0.856 \\
\hline $\mathrm{X} 3.2$ & & & & & & 0.897 \\
\hline $\mathrm{X} 3.3$ & & & & & & 0.861 \\
\hline $\mathrm{X} 4.1$ & & & & & 0.791 & \\
\hline $\mathrm{X} 4.2$ & & & & & 0.932 & \\
\hline $\mathrm{X} 4.3$ & & & & & 0.834 & \\
\hline $\mathrm{X} 5$ & & & & 1.000 & & \\
\hline Y.1 & & 0.787 & & & & \\
\hline Y.2 & & 0.820 & & & & \\
\hline Y.3 & & 0.950 & & & & \\
\hline Y.4 & & 0.949 & & & & \\
\hline Y.5 & & 0.944 & & & & \\
\hline
\end{tabular}

lation item score/component score that is estimated using PLS software. Score value loading of between 0.5 and 0.6 is considered sufficient(Hair et al., 2014).

\section{Outer Loading}

Outer loading is used to test the validity of the variables that are used in a research. Table 3 presents results of the test on outer loading Collaborative Governance in the management of international border areas in Riau Province.

Based on analysis results, all indicators that were drawn from variables used in the research had a value that is higher than 0.5 , which shows that variables that comprise Collaborative Governance passed the validity convergence test.

\section{Average Variances Extracted}

Beside the outer loading technique, the value of AVE (Average Variances Extracted) loading was also used to test convergent validity. If the value of AVE was higher than 0.50 that indicates that the value of the construct was at least $50 \%$ of the variance.

Based on results of the analysis (Table 4), it was evident that the values of AVE (Average Variances Extracted) for all variables was higher than 0.5 . The implication of that is that all variables full filled convergent validity requirement.

\section{Composite Reliability}

Composite Reliability determines the extent to output from PLS (table 5). In addition composite reliability table can be used 
Table 4. AVE (Average Variances Extracted) results

\begin{tabular}{lc}
\hline \multicolumn{1}{c}{ Variable } & $\begin{array}{c}\text { Average Variance Ex- } \\
\text { tracted (AVE) }\end{array}$ \\
\hline Collaborative Culture & 0.660 \\
\hline Collaborative Governance & 0.798 \\
\hline Collaborative Leadership & 0.700 \\
\hline Collaborative Structure & 1.000 \\
\hline Collaborative Team & 0.730 \\
\hline Strategic Vision & 0.760 \\
\hline
\end{tabular}

to evaluate a construct of collaborative governance.

Based on Table 5, it is apparent that the value of composite reliability for all variables is higher than 0.700 . That shows that the instrument used had high consistence and stability. In other words, the instruments full filed the reliability requirement.

To that end, the conclusion that the conduct of the outer model test, which consists of discriminant validity and convergent Validity tests has been done. That means that all the data used in the research fulfils all the requirements to be used in the subsequent research analysis.

Figure 1 shows the correlation coefficients of some of the 5 (five) variable that comprise Collaborative Governance in the management of international border areas in Riau islands province.

Analysis results obtained using Smart PLS V.3 program as presented in table 6 can be interpreted as follows:

1. The contribution of Collaborative culture to the formation of collaborative governance has a magnitude of 0.212 with $\mathrm{p}$-value 0.000 . Since the $\mathrm{p}$-value is lower than $0.05(0.000<0.05)$ collaborative culture has strong influence on the formation of collaborative governance.

2. The contribution of Collaborative leadership to the formation of collaborative governance has a magnitude of 0.207 with $t$ statistic of 5.289 and $p$-value 0.000 . Since $\mathrm{p}$-value for the coefficient is lower than $0.05(0.000<0.05)$, it can be concluded that collaborative leadership has significant contribution to the formation of collaborative governance.

3. The contribution of collaborative structure to the formation of collaborative governance has a magnitude of 0.230 and $p$-value 0.006 . Since pvalue for the coefficient is lower than $0.05(0.005<0.05)$, it can be concluded that collaborative structure has strong contribution to the formation of collaborative governance.

4. The contribution of collaborative team to the formation of collaborative governance has a magnitude of 0.281 and $\mathrm{p}$-value 0.027 . Since $\mathrm{p}$-value for the coefficient is lowers than $0.05(0.027<$ $0.05)$, the conclusion that can be drawn is that collaborative team has significant contribution to the formation of collaborative governance.

5. The contribution of strategic vision to the formation of collaborative governance has a magnitude of 0.174 , and $\mathrm{p}$ value 0.165 . Since $p$-value is larger than $0.05(0.165>0.05)$ it can be concluded that strategic vision does not contribute significantly to the formation of collaborative governance.

Results of the analysis of collaborative governance model obtained by using PLS showed that Collaborative Team Process (CTP) has the largest influence. The contribution of CTP variable to the formation of collaborative governance was in the order of 0.281 , followed by Structure variable (0.230), Culture (0.212), Leadership (0.207) and Strategic visions (0.174).

The first variable is Collaborative Culture. The perception of some of the respond- 
Adji Suradji Muhammad, Tulus Warsito, Ulung Pribadi, Achmad Nurmandi - Collaborative Governance...

Table 5. Composite Reliability for CG construct

\begin{tabular}{ll}
\hline \multicolumn{1}{c}{ Variable } & Composite Reliability \\
\hline Collaborative Culture & 0.853 \\
\hline Collaborative Governance & 0.951 \\
\hline Collaborative Leadership & 0.875 \\
\hline Collaborative Structure & 1.000 \\
\hline Collaborative Team & 0.890 \\
\hline Strategic Vision & 0.905 \\
\hline
\end{tabular}

ents was that Collaborative Culture had run smoothly", $78.26 \%$ perceived it to be low and no respondents perceived the variable to be high or $0 \%$. This shows that collaborative culture plays a very small role in the management of international borders in Riau islands province. The research finding corroborates finding by Endang Rudiatin (2012) in a research on Integration of Local Economy in International border region that the process of economic integration is fraught with various social and cultural, political expression, information network flows, and center of public interaction within various social, economic, ethnic, and religious backgrounds, as well as a combination of rivaling, cooperating, colluding, competing, and conflicting cultural groups. On the contrary, according to Emerson 2, involvement in collaboration is constrained by disparity in resources of parties attributable to differences in language, culture and habits. "Resource disparities among participants are often highlighted in cross-cultural settings, where language, customs, and culture can present barriers to engagement" (Emerson et al., 2012).

Collaborative Leadership is the second variable in importance. Leadership holds the ultimate accountability in an institution. Leadership that is flexible and easy to forge collaboration with other parties, especially involving in executing tasks and functions, find it easy to achieve their goals. On the contrary, leaders who are reluctant or avoid engaging in collaboration with other parties that are charged with executing the same tasks and functions, are a major obstacle to achieving goals. Based on results of the questionnaire that was sent to respondents, $100 \%$ perceived the performance of leadership or institutions that are charged with the responsibility of managing international borders to be low. The state of affairs (low collaborative leadership) is very much contrary to developments in the World today that demands collaborative leadership and facilitator to meet existing challenges. Collaboration can be constrained if leaders of groups that are involved in collaboration are not innovative enough in achieving increasingly complex political goals that have the potential to spark internecine conflict (Sudarmo, 2011). Such an argument is elucidated in (Huxom. \& Vangen, 2000), by underscoring recent developments that point to "New work in this area provides excellent insights on the concept of facilitative, collaborative leadership appropriate for the post? Industrial world of the next century." The importance of Collaborative leadership is confirmed by (Firman, 2010), who reiterates that there are four factors that are key to successful management of pollution and infrastructure under the coordination of the Kartamantul secretariat. The four factors include first, collective decision making process, secondly, existence of transparency and openness in conducting negotiations between parties and thirdly, leadership with collective vision, and fourthly, every leader share their perspectives on the importance of synergy in development.

The third variable is Collaborative Structure. Considering the fact that the process of managing international border region involves 23 government institutions, both national and local government level, makes the existence of a strong structure imperative. Collaboration among organizational structures strengthen existing collaboration. Based on the perception of respondents to (CC) dimension, $91.30 \%$ of respondents considered the performance of the dimen- 


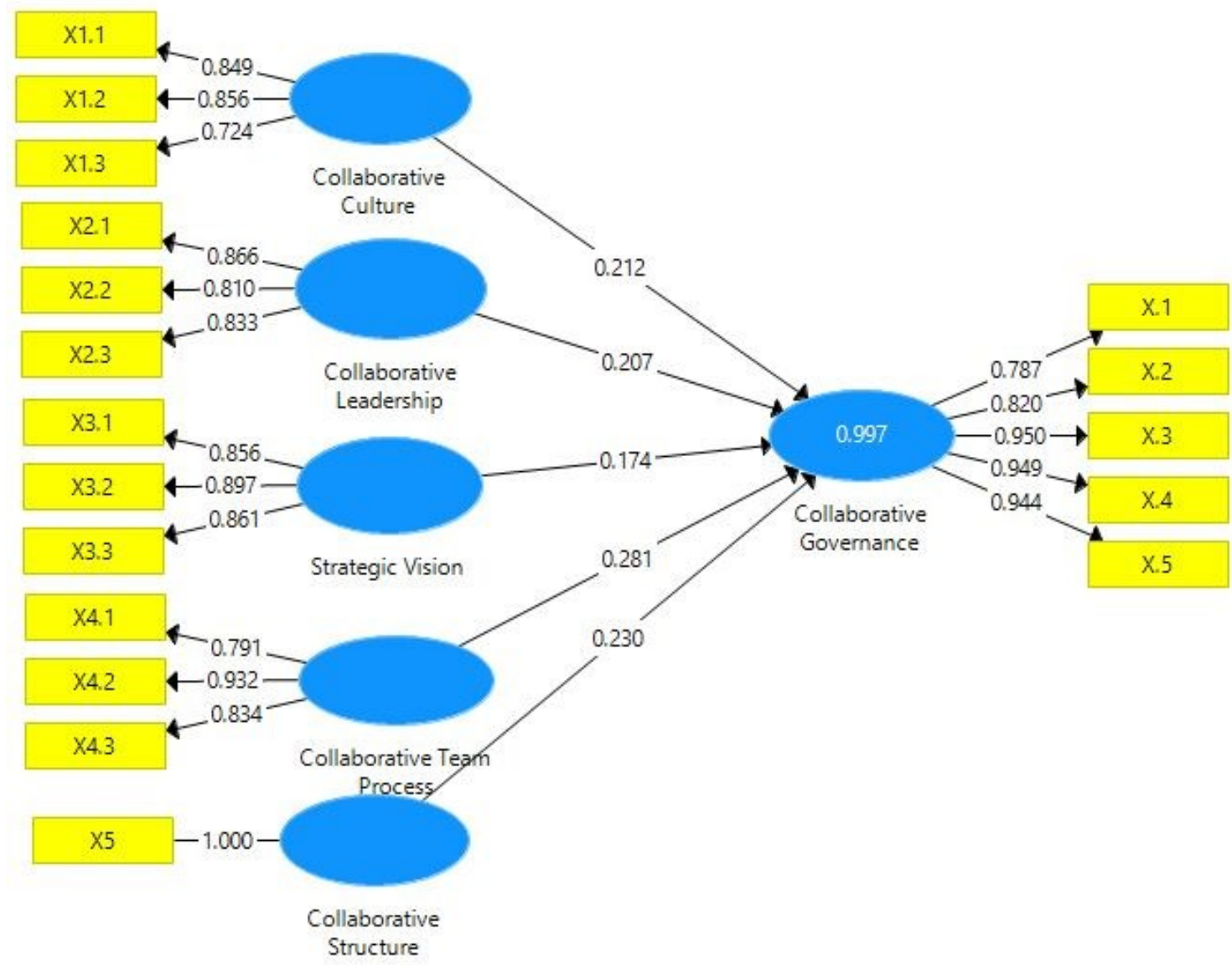

Figure 1. Collaborative Governance Formation Model in the Management of International border areas in Riau Islands Province

sion low. The rest perceived it as adequate. Such an overwhelmingly low perception of respondents about the performance of collaborative structure variable, attests to the fact that collaborative structure still plays a very small role in the management of international border region in Riau Islands province. This is contrary to what the prevailing conditions require. Ideally, construction that is gathering pace in the region, should involve many organizational structures to be effective and efficient. The perception of respondents concurs with results of a research by Indra Pahlevi (2011) on regions. Findings of the research noted that despite the fact that there are many policies, planning, and programs that have been implemented by Ministries/institutions, the general public have yet to perceive significant change in direction in policy since the creation of a new province was made which is coupled by the state of physical facilities that remains suboptimal. This is in line with findings by Firman (2010) who underscored the importance of "an effective structure in strengthening operations of a joint secretariat in overcoming challenges of growth and development in Kartamantul region in the near future".

The fourth variable is Collaborative Team Process, which is part and parcel of implementing programs and activities based on prior planning. The success of a program or activity depends on whether or not the team forges collaboration with other teams. The expectation collaboration among stakeholders contributes to the success of the program (Johnston, Hicks, Nan, \& Auer, 2011). Based on results from the questionnaire, $82.61 \%$ of respondents perceived the level of current collaboration among teams 
Adji Suradji Muhammad, Tulus Warsito, Ulung Pribadi, Achmad Nurmandi - Collaborative Governance...

Table 6. Constituent Variables of CG in the Management of International border areas in Riau Islands province

\begin{tabular}{lccccc}
\hline & $\begin{array}{c}\text { original } \\
\text { sample }\end{array}$ & $\begin{array}{c}\text { standard } \\
\text { deviation }\end{array}$ & t statistik & p value & Relationship \\
\hline Collaborative Culture $=>$ CG & 0.212 & 0.044 & 4.782 & 0.000 & Low \\
\hline $\begin{array}{l}\text { Collaborative Leadership }=> \\
\text { CG }\end{array}$ & 0.207 & 0.039 & 5.289 & 0.000 & Low \\
\hline Collaborative Structure $=>$ CG & 0.230 & 0.090 & 2.552 & 0.006 & Low \\
\hline Collaborative Team $=>$ CG & 0.281 & 0.145 & 1.936 & 0.027 & Low \\
\hline Strategic Vision $=>$ CG & 0.174 & 0.178 & 0.975 & 0.165 & Very low \\
\hline
\end{tabular}

which has become the culture of 'doing business' in the area, to be low. This findings confirms fears that collaboration in the management of international borders in Riau Islands province is still detached (separated) in accordance with interests of the participating parties. Sector- centricism is still an obstacle that hampers collaboration. Minimizing even eradicating ego sector tendencies requires dialogue that involve all the stakeholders. Dialog is an effective way for stakeholders to exchange information, and helps in finding common ground on areas of disagreement among parties. The importance of dialog is confirmed by (Tschirhart et al., 2005), who contends that " resolving conflict may be tackled either through information exchange (a 'dialogue') or with the aim of reaching a joint agreement (a 'negotiated settlement')". Anderson (2004) shares the same argument, by noting that as a process, collaboration is an interaction among several individuals in sustainable manner. Collaboration, requires collective planning through accountability in implementing tasks and activities. This commensurate with Lindeke and Sieckert (2005) who contends that collaboration beng a complex process requires deliberate and planned sharing of knowledge, which become collective responsibility of all parties in the collaboration.

Strategic Vision is the last variable. Vision or long term view point, is strategically important in collaboration. The existence of collaboration that is underpinned by a long term common vision is persistent rather than incidental or short term. This is important given the need for a strategic vision, which is only possible if the perception of all stakeholders is the same. Nonetheless, it is regrettable that the current strategic vision in the management of international borders in Riau islands province has not lived to expectations. This was reflected in the perception of respondents, $78.26 \%$ of whom considered the process of formulating the strategic vision in the management of International borders to be low. The rest perceived the process to be adequate $(21.74 \%)$. Low perception about the performance of strategic vision in the management of international borders is in part attributable to the non-participatory nature of the existing blueprint on the management of international border areas in Riau Islands province. The formulation of the existing blue print which is part of the Master plan for the Management of International borders, 2015-2019" did involve stakeholders representatives of institutions that are manage international borders at the local government level. This is despite the fact that geographically and practically, understanding of the management of international borders transcends that of institutions at the central government level. The collective formulation of strategic vision is important in creating trust among stakeholders. This is in line with findings of a research by Saru Arifin (2011) on the management of International borders in West Kalimantan province that share borders with Sarawak, Malaysia. Results of the research showed that some of the factors that are attributable for the irrelevancy of the development model to characteristics of international border area, among others include; sector 
centered bureaucracy culture, weak authority vested in the Local government Agency for the Management of International Borders, inconsistence of policy with international border development paradigm implemented by relevant ministries, and remote geographical conditions that require special management. The finding falls in line with Firman (2010) research results that "......and fourth, the heads of the involved local governments share the common vision that urban infrastructure development should be implemented in a synergistic way in order to provide better quality public service". In the same vein, (O' Flynn \& Alford, 2008) also stressed the factor of limited interaction among stakeholders for strengthening the polarized positions and interests of each to the detriment of the collaboration, "made it difficult for them to maintain the type of collaborative relationship which might build trust and thereby engender the sharing of information". Formulating a joint strategy, may start from the existence of confrontation among parties. This is because confrontation is a natural process(Tschirhart, Christensen, \& Perry, 2005). To that end, if points of contention are presented openly in a forum that involves all stakeholders will help in highlighting positions of every party, paving way for an effective collaboration in the end.

\section{CONCLUSION}

Collaboration among stakeholders in the management of International borders at the central and local government level in Riau Islands province is still weak. This is reflected in the performance of five principles of Collaborative Governance, which were postulated by Djumara (2008) inter alia, Collaborative Culture, Collaborative Leadership, Strategic Vision, Collaborative Team Process, and Collaborative Structure that is still suboptimal. Of the five principles, only Collaborative Team Process (CTP) showed the highest influence on collaborative government. The CTP variable registered the largest contribution to the formation of collaborative governance, following by structure, culture, leadership and strategic vision, in that order. Supporting factors for Collaborative Governance process in the management of international borders in Riau Islands province include availability of sufficient government personnel and sufficient natural resources. Meanwhile, factors that are still obstacles to the Collaborative Governance process include lack of commitment from all parties, absence of trust among stakeholders, and limited access to information, and insufficient coordination.

As regards advice for better management of international border areas in future, the author recommends the formation of a task force. The task force must involve all stakeholders that have authority or responsibility to manage international border regions, at the national and sub national government level. Implementing that will lead to improvement in commination, information exchange, commitment and coordination required to ensure sustainable collaboration.

\section{REFERENCES}

Anderson, E. T., \& McFarlane, J. M. (2000). Community as partner: theory and practice in nursing. AmericanJournal of Nursing, 96, xx, 472.

Arifin, Saru. (2014), Hukum Perbatasan Antarnegra, Sinar Grafika.

Darmaputra, Rizal. (2009). Manajemen Perbatasan dan Reformasi Sektor Keamanan, Jakarta: IDSPS Press.

Djumara, N. (2008). Kolaborasi dan Jejaring Kerja. Jakarta: Lembaga Administrasi Negara-RI.

Suradinata, Ermaya, (1998), Manajemen Pemerintahan dan Otonomi Daerah, Bandung, Ramadan.

Emerson, K., Nabatchi, T., \& Balogh, S. (2012). An integrative framework for collaborative governance. Journal of Public Administration Research ..., 22 (1), 1-29.

Firman, T. (2010). Multi local-government under Indonesia's decentralization reform: The case of Kartamantul (The Greater Yogyakarta). Habitat International, 34(4), 400-405.

Gray, B., \& Wood, D. J. (1991). Collaborative Alliances: Moving from Practice to Theory. The Journal of Applied Behavioral Science, 27(1), 3-22. 
Adji Suradji Muhammad, Tulus Warsito, Ulung Pribadi, Achmad Nurmandi - Collaborative Governance...

Hair, J. F. J., Sarstedt, M., Hopkins, L., \& Kuppelwieser, V. G. (2014). Partial least squares structural equation modeling (PLS-SEM). European Business Review (Vol. 26).

Huxom., C., \& Vangen, S. (2000). Leadership in the shaping and implementation of collaborative agendas: how things happen in a (not quite) joined up world. Academy of Management Journal, 43(6), 1159-1175.

Johnston, E. W., Hicks, D., Nan, N., \& Auer, J. C. (2011). Managing the inclusion process in collaborative governance. Journal of Public Administration Research and Theory, 21(4), 699-721. $\mathrm{h}$

Lai, E. R. (2011). Critical thinking: A literature review. Critical Thinking, (June), 1-49. Retrieved from http:// images.pearsonassessments.com/ images/tmrs/ CriticalThinkingReviewFINAL.pdf

Lindeke, L. L., \& Sieckert, A. M. (2005). Nurse-physician workplace collaboration. Online Journal of Issues in Nursing, 10(October), 5.

Marshall, Edward M, Transforming The Way We Work: The Power of the Collaborative Work Place.
Newman, J., Barnes, M., Sullivan, H., \& Knops, A. (2004). Public Participation and Collaborative Governance. Journal of Social Policy, 33(2), 203-223.

O' Flynn, J., \& Alford, J. (2008). The Separation/Specification Dilemma In Contracting: The Local Government Experience In Victoria. Public Administration, 86(1), 205-224.

Pahlevi, Indra. (2011), Pengelolaan Pemerintahan Di Wilayah Perbatasan Peneliti Masalah Politik dan Pemerintahan Indonesia, Bidang Pengkajian P3DI Setjen DPRRI

Richie, L., Oppenheimer, J. D., \& Clark, S. G. (2012). Social process in grizzly bear management: Lessons for collaborative governance and natural resource policy. Policy Sciences, 45(3), 265-291.

Sudarmo, (2011), Isu-Isu Administrasi Publik Dalam Perspektif Governance, SMART Media, MAP UNS

Tschirhart, M., Christensen, R. K., \& Perry, J. L. (2005). The Paradox of Branding and Collaboration. Performance \& Management Review, 29(1), 67-84. 